\title{
Breeding sites of drosophilids (Diptera) in the Brazilian Savanna. I. Fallen fruits of Emmotum nitens (Icacinaceae), Hancornia speciosa (Apocynaceae) and Anacardium humile (Anacardiaceae)
}

\author{
Francisco Roque ${ }^{1}$, John Du Vall Hay² \& Rosana Tidon ${ }^{3}$
}

${ }^{1}$ Pós-graduação em Ecologia, Instituto de Ciências Biológicas, Universidade de Brasília, ICC Sul, térreo, Campus Universitário Darcy Ribeiro, Asa Norte, 70910-900 Brasília-DF, Brasil. roque9@bol.com.br

${ }^{2}$ Departamento de Ecologia, Instituto de Ciências Biológicas, Universidade de Brasília, ICC Sul, térreo, Campus Universitário Darcy Ribeiro, Asa Norte, 70910-900 Brasília-DF, Brasil. jhay@unb.br

${ }^{3}$ Departamento de Genética e Morfologia, Instituto de Ciências Biológicas, Universidade de Brasília, Asa Norte, Caixa Postal 04457, 70919-970 Brasília-DF, Brasil. rotidon@unb.br

\begin{abstract}
Breeding sites of drosophilids (Diptera) in the Brazilian Savanna. I. Fallen fruits of Emmotum nitens (Icacinaceae), Hancornia speciosa (Apocynaceae) and Anacardium humile (Anacardiaceae). In this study, drosophilids that bred in fruits of three common plant species of the Brazilian Savanna were investigated: Emmotum nitens, Hancornia speciosa and Anacardium humile, along with the temporal and spatial distribution of these insects among fruits obtained from six individuals of E. nitens. Fallen fruits were collected in natural environments, placed on moist sand in individual containers and all drosophilids that emerged from these resources during 15 days were collected, counted and identified. From 3,651 fruits collected (3,435 of E. nitens, 179 of A. humile and 37 of H. speciosa) 4,541 flies emerged and were classified into 19 species of Drosophilidae. Their distribution was unequal among the three resources, also over time, and among the six individuals of E. nitens. Such fluctuations probably reflect the availability of resources in time and space and probably the action of selective factors such as larval competition.
\end{abstract}

KEYWORDS. Biodiversity; Cerrado biome; Drosophila.

RESUMO. Sítios de criação de drosofilídeos (Diptera) no bioma Cerrado. I. Frutos caídos de Emmotum nitens (Icacinaceae), Hancornia speciosa (Apocynaceae) e Anacardium humile (Anacardiaceae). Neste estudo, são investigados os drosofilídeos que se criam em frutos de três espécies de plantas comuns do Cerrado brasileiro: Emmotum nitens, Hancornia speciosa e Anacardium humile, juntamente com a distribuição temporal e espacial desses insetos entre os frutos obtidos de seis indivíduos de E. nitens. Frutos recolhidos sobre a serrapilheira, em ambientes naturais, foram mantidos no laboratório e os drosofilídeos que deles emergiram foram contados e identificados. Dos 3.651 frutos coletados (3.435 de E. nitens, 179 de A. humile e 37 de H. speciosa) emergiram 4.541 drosofilídeos, classificados em 19 espécies. A distribuição dessas espécies foi desigual entre os três tipos de recursos, ao longo do tempo, e também entre os seis indivíduos de E. nitens. Essas flutuações refletem a disponibilidade dos recursos no tempo e no espaço, e provavelmente a ação de forças seletivas como a competição entre as larvas.

PALAVRAS-CHAVE. Biodiversidade; Drosophila; savana brasileira.

The distribution of organisms varies in space and time, and is strongly influenced by environmental heterogeneity. Changes in temperature, humidity, and resource availability, among other factors, can alter the size, density, and distribution of populations. A portion of these variations has evolutionary meaning, because it can alter the structure and genetic composition of the populations. However, although the relationships between organisms and environments are a central issue in ecology, they are still poorly understood (Begon et al. 2006).

Drosophilids are considered excellent models for biological research (Powell 1997), but little is known about their ecology, especially in tropical environments (Val et al. 1981; Tidon 2006). These flies breed in a wide variety of organic substrates, including fallen fruits, flowers, slime fluxes, and fleshy fungi (Carson 1971). During their decomposition, these substrates attract flies due the presence of microorganisms, principally yeasts, which constitute the alimentary base for these insects
(Powell 1997). Tropical zones appear to be characterized by an "unlimited" supply of available fruits for drosophilids, and previous papers identified the drosophilid species associated with different fruits in Africa (Lachaise \& Tsacas 1983) and Southern South America (Brncic \& Valente 1978; Araújo \& Valente 1981; Pereira et al. 1983; Valente \& Araujo 1986; Bonorino \& Valente 1989; Valente \& Araujo 1991; Rohde \& Valente 1996; Vilela 2001). In the Brazilian Savanna, however, the only fruit studied thus far was Solanum lycocarpum (Solanaceae) (Leão \& Tidon 2004). Valente \& Araújo (1986) have investigated two species in the family Anacardiaceae (Mangifera indica and Spondias mombin) as breeding sites for drosophilids, but this is the first study investigating drosophilids associated with species of Apocynaceae and Icacinaceae in the Neotropical Region.

The Brazilian Savanna, locally known as the Cerrado biome, is the largest region of savanna in a single country, covering approximately 2 million $\mathrm{km}^{2}$ (Oliveira \& Marquis 2002). It is 
considered a biodiversity hotspot, because it is one of the least known and most endangered areas in the world, having had more than $60 \%$ of its native vegetation destroyed, mainly in consequence of human activities (Myers et al. 2000). Its climate is seasonal, wet from October to March and dry from April to September, with temperatures ranging from $22^{\circ} \mathrm{C}$ to $27^{\circ} \mathrm{C}$ (Klink \& Machado 2005). This savanna is a mosaic of physiognomic vegetation forms, ranging from dense grassland, usually with a sparse cover of shrubs and small trees, to almost closed woodland, with a canopy height of 12 $15 \mathrm{~m}$ (Ratter et al. 1997). These vegetation types have different structures and species composition, and the transition between them varies from sharp to gradual.

The drosophilid assemblages of the Brazilian Savanna vary in space and time, but the causes of these fluctuations are still unknown (Tidon 2006). According to Wolda (1988), insect populations can respond to micro and macroclimatic changes, as well as to alterations in resource availability. Therefore, understanding the feeding and breeding habits of these flies is important to explain their relationship to the environment (Toda 1973; Tidon 2006). This study is part of a broader project, aimed at investigating the relationship between drosophilid flies and the environment where they occur in the Brazilian Savanna. The objectives here were (1) to characterize the assemblages of drosophilids breeding in fallen fruits of three common plants of the Brazilian Savanna: Emmotum nitens (Icacinaceae), Hancornia speciosa (Apocynaceae) and Anacardium humile (Anacardiaceae) and (2) to evaluate the spatial and temporal distribution of these insects among fruits obtained from individuals of $E$. nitens.

\section{MATERIALAND METHODS}

Fallen fruits of the focal species were collected in fragments of natural vegetation at two sites in the municipality of Sobradinho, a town of Distrito Federal located in the vicinity of Brasilia. At site 1 (ca. 37.2 ha, located at $15^{\circ} 37^{\prime} \mathrm{S} ; 47^{\circ} 47^{\prime} \mathrm{W}$ ), fallen fruits were obtained around six trees of Emmotum nitens and 14 trees of Hancornia speciosa, in environments of dystrophic cerradão and cerrado sensu stricto, respectively. At site 2 (ca. 96.5 ha, located at $15^{\circ} 38^{\prime} \mathrm{S} ; 47^{\circ} 44^{\prime} \mathrm{W}$ ), fallen fruits were collected around 32 trees of Anacardium humile, in an area with a predominance of campo sujo. Detailed descriptions of these vegetation types can be found in Oliveira $\&$ Marquis (2002). The geographic locations were obtained with a Garmin II GPS. Fruits were collected weekly, from October 2005 to February 2006, which covered the dispersal period of the focal plants. We collected all fruits found on the ground around each focal individual. The sample size of each collection, however, varied in accordance with the availability of fruits.

Emmotum nitens Miers belongs to the pantropical family Icacinaceae, which includes 12 American genera whose center of origin is the Amazon basin (Barroso et al. 1984). It is popularly known as sobre or faia, and can reach $10 \mathrm{~m}$ in height. This species is considered an indicator of dystrophic cerradões, which are areas with nutrient poor soil and predominately evergreen vegetation (Ratter et al. 1973). The fruits are fleshy, about $2 \mathrm{~cm}$ in diameter and $5 \mathrm{~g}$ in weight, and have an unpleasant odor. They are resistant due to a woody endocarp involving the seed that acts as a barrier against insects, fire and other external factors.

Hancornia speciosa Gomez belongs to the widely distributed family Apocynaceae, which includes more than 4,500 species classified into 415 genera. Commonly known as mangaba, this fruit is berry, ellipsoid to globoid, yellowish green or rosy green, with viscous, whitish pulp, from 2.6 to 4 $\mathrm{cm}$ in diameter (Almeida et al. 1998).

Anacardium humile St. Hil. is classified in the family Anacardiaceae, which includes 70 genera and about 600 species of tropical and subtropical distribution, with some representatives in temperate areas. Popularly known as cajuzinho-do-cerrado, this is a typical plant of campo sujo and cerrado. Its fruit is a true nut, and its comestible part is the pseudofruit, located at the apex of the fruit, approximately $1.5 \mathrm{~cm}$ in diameter, which is red, claviform, and has white and succulent pulp (Almeida et al. 1998).

All fruits found on the ground in the vicinity of each individual were collected, placed in a separate labeled plastic bag and taken to the laboratory where each bag was weighed and the number of fruits counted. After counting, fruits obtained from the same tree were placed on a bed of moist sand in individual containers plugged with synthetic foam stoppers. The containers were maintained at constant temperature $\left(25 \pm 1^{\circ} \mathrm{C}\right)$ and photoperiod ( $13 \mathrm{~h}$ : $11 \mathrm{~h}$, Light: Dark). Water was added when necessary to prevent desiccation using a manual plant sprayer. All emerged insects were removed daily with a small vacuum cleaner. After the first emergence this procedure was continued for only 15 days in order to avoid overlapping of generations since if any individual was not collected on the first day this is the minimum interval for the second generation to emerge. The captured specimens were identified using keys, descriptions and, in some cases, by the analysis of the male terminalia (Freire-Maia \& Pavan 1949; Pavan \& Nacrur 1950; Frota-Pessoa 1954; Magalhães 1962; Val 1982; Vilela 1983; Vilela \& Bächli 1990; Chassagnard \& Tsacas 1993). The species were classified into three groups: 1: Zaprionus indianus (ZAP) which was recently introduced into the South America (Vilela 1999), 2: other exotic species (EXO), and 3: endemic species of the Neotropical Region (NEO). References to the taxonomic authorities can be found in the Drosophilidae taxonomy database compiled by Bächli (2008) and Brake \& Bächli (2008). Voucher specimens of the captured insects were deposited in the collection of the Laboratório de Biologia Evolutiva of the Instituto de Ciências Biológicas of the Universidade de Brasília.

Weekly-based accumulation curves for drosophilid species were compiled separately for each plant species, to assess sample representivity. Species accumulation curves, Chao 1, were generated using Estimate S 7.5 (Colwell 2005). The drosophilids that emerged from each resource were analyzed by composition and relative abundance of species and by the 
density of flies per gram of fruit. Tests for statistically significant differences in the relative abundance of Neotropical and exotic species among the three plant species were done using a Chi-square test at $\alpha=0.01$ significance level. For Emmotum nitens, the density of flies was tested for spatial (six trees) and temporal (five months) variables by simple linear regression.

\section{RESULTS}

From the 3,651 fruits collected (3,435 of Emmotum nitens, 37 of Hancornia speciosa, and 179 of Anacardium humile) 4,541 drosophilids emerged and were classified into 16 species of Drosophila Fallén and one species of each of the following genera: Rhinoleucophenga Hendel, Scaptodrosophila Duda and Zaprionus Coquillett (Table I). Specimens of coleoptera, lepidoptera and species of the families Tephritidae (Diptera) and Vespidae (Hymenoptera) also emerged.

Although the accumulation curves did not reach an asymptote, the highest species richness seemed to be associated with Emmotum nitens and the lowest with Anacardium humile (Fig. 1). Drosophila nebulosa and D. simulans emerged from fruits of all plant species and were the only drosophilids registered in A. humile. The remaining fly species usually emerged from a single substrate type (Table I). The proportion of Neotropical and exotic species also varied among the three resources $\left(\chi^{2}=6.63 ; \mathrm{df}=1 ; p<0.01\right)$ : the

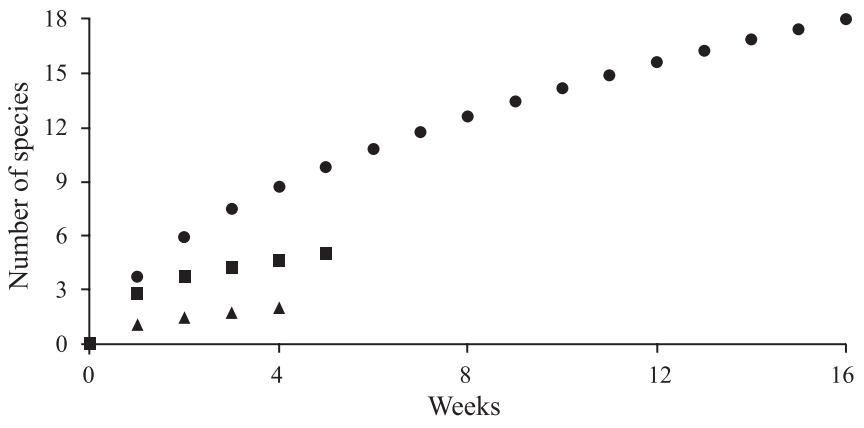

Fig. 1. Accumulation curves for drosophilid species that emerged from Emmotum nitens ( $\mathrm{n}=3435$, from October 2005 to February 2006), Hancornia speciosa $(\mathbf{\square} ; \mathrm{n}=37$, November 2005) and Anacardium humile ( $\mathbf{\Delta} ; \mathrm{n}=179$, October 2005). Data randomized 1,000 times using Estimate S 7.5 (Colwell 2005).

fauna associated with $E$. nitens was dominated by Neotropical species, whereas in A. humile and Hancornia speciosa the exotics D. simulans and Zaprionus indianus, predominated respectively (Fig. 2).

The distribution of drosophilids in Emmotum nitens varied among the six trees and in successive months of collection (Fig. 3). Three of the six studied trees showed the highest richness, abundance and density of drosophilids (Table II). The abundance of flies was related to the weight of fruits of each tree $\left(r^{2}=0.98\right)$ as well as to the total number of fruits

Table I. Drosophilids emerged in laboratory from fallen fruits of Emmotum nitens, Hancornia speciosa and Anacardium humile collected from October 2005 to February 2006 in the municipality of Sobradinho, Distrito Federal, Brazil. n = number of fruits.

\begin{tabular}{|c|c|c|c|c|}
\hline \multirow[b]{2}{*}{ Drosophilid species } & \multicolumn{3}{|c|}{ Plant species } & \multirow[b]{2}{*}{ Total } \\
\hline & $\begin{array}{l}\text { E. nitens } \\
(\mathrm{n}=3,435)\end{array}$ & $\begin{array}{l}\text { H. speciosa } \\
(\mathrm{n}=37)\end{array}$ & $\begin{array}{l}\text { A. humile } \\
(\mathrm{n}=179)\end{array}$ & \\
\hline Drosophila nebulosa Sturtevant, 1916 & 2,032 & 118 & 1 & 2,151 \\
\hline Zaprionus indianus Gupta, 1970 & 1,024 & 222 & - & 1,246 \\
\hline D. willistoni Sturtevant, 1916 & 875 & - & - & 875 \\
\hline D. simulans Sturtevant, 1919 & 117 & 2 & 19 & 138 \\
\hline D. bocainensis Pavan and da Cunha, 1947 & 57 & - & - & 57 \\
\hline D. mediostriata Duda, 1925 & 23 & - & - & 23 \\
\hline D. cardini Sturtevant, 1916 & 12 & 4 & - & 16 \\
\hline Rhinoleucophenga sp. A & - & 12 & - & 12 \\
\hline D. immigrans Sturtevant, 1916 & 6 & - & - & 6 \\
\hline D. cardinoides Dobzhansky and Pavan, 1943 & 3 & - & - & 3 \\
\hline D. paraguayensis Duda, 1927 & 3 & - & - & 3 \\
\hline Drosophila sp. A & 3 & - & - & 3 \\
\hline D. sturtevanti Duda, 1927 & 2 & - & - & 2 \\
\hline D. arauna Pavan and Nacrur, 1950 & 1 & - & - & 1 \\
\hline D. mercatorum Patterson \& Wheeler, 1942 & 1 & - & - & 1 \\
\hline D. mesostigma Frota-Pessoa, 1954 & 1 & - & - & 1 \\
\hline D. ornatifrons Duda, 1927 & 1 & - & - & 1 \\
\hline D. polymorpha Dobzhansky and Pavan, 1943 & 1 & - & - & 1 \\
\hline Scaptodrosophila latifasciaeformis Duda, 1940 & 1 & - & - & 1 \\
\hline Total number of drosophilids & 4,163 & 358 & 20 & 4,541 \\
\hline Total fruit weight $(\mathrm{g})$ & 14,969 & 753 & 606 & 16,328 \\
\hline Drosophilids/g fruit & 0.278 & 0.476 & 0.033 & 0.278 \\
\hline
\end{tabular}

* Singleton species were represented by males, except S. latifasciaeformis. 


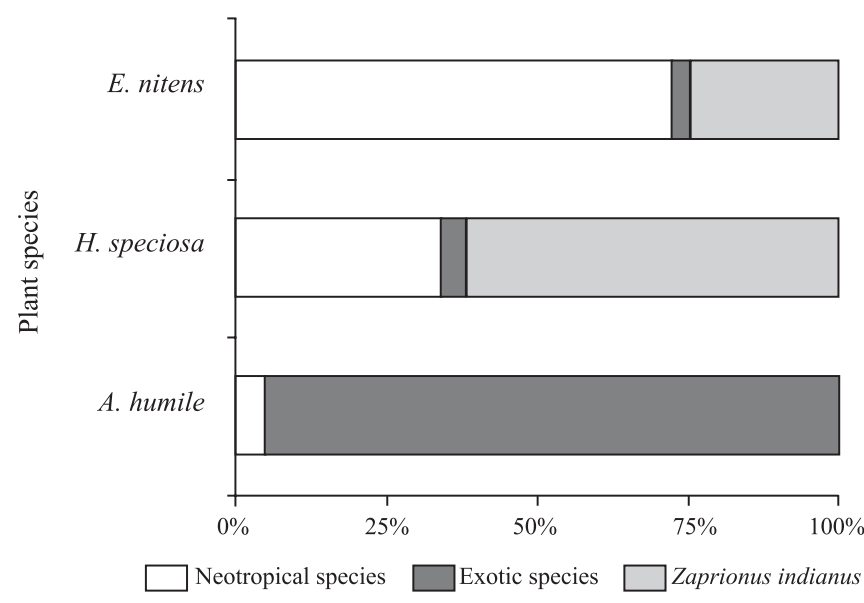

Fig. 2. Percentage of emergence of three categories of drosophilids in fruits of Emmotum nitens, Hancornia speciosa, and Anacardium humile.

produced along the months $\left(\mathrm{r}^{2}=0.95\right)$. Trees that produced more fruits had longer fruiting periods, about three months. The population peak of drosophilid in fruits of $E$. nitens was in January, when the availability of fruits was also higher (Fig. 3).

\section{DISCUSSION}

The drosophilid assemblages of the Brazilian Savanna vary in space and time, and can respond to micro and macroclimatic changes, as well as to alterations in resource availability. The fruits evaluated here are exploited by these flies in different manners.

An increase in the density of these flies does not necessarily correspond to an increase in species diversity. The highest density of drosophilids was recorded in fruits of Hancornia speciosa, but the highest richness occurred in Emmotum nitens. Rotting fruits of E. nitens were available in the environment for these insects throughout five months, and were used as breeding site by 18 species of drosophilids. H. speciosa and Anacardium humile, on the other hand, presented relatively briefer periods of fructification, one month each, and had fewer drosophilid species associated with them. These last two species of plant seems to be ephemeral resources that are exploited mainly by opportunistic species, such as Drosophila nebulosa, D. simulans and Zaprionus indianus, that belong to introduced and/or widely distributed species in South America (Tidon et al. 2003; Tidon 2006).

The highest diversity of drosophilids in Emmotum nitens is probably due to the type of environment where these plants live. Most species of these flies avoid environments that are too dry, bright or hot (Grossfield 1978), and are associated with forest habitats, such as the cerradões where E. nitens occurs. Therefore, we suggest that fallen fruits of E. nitens are an important resource for the maintenance of drosophilid populations, since this species produces fruits in habitats well suited for many species of drosophilids and for a relative long period of time.

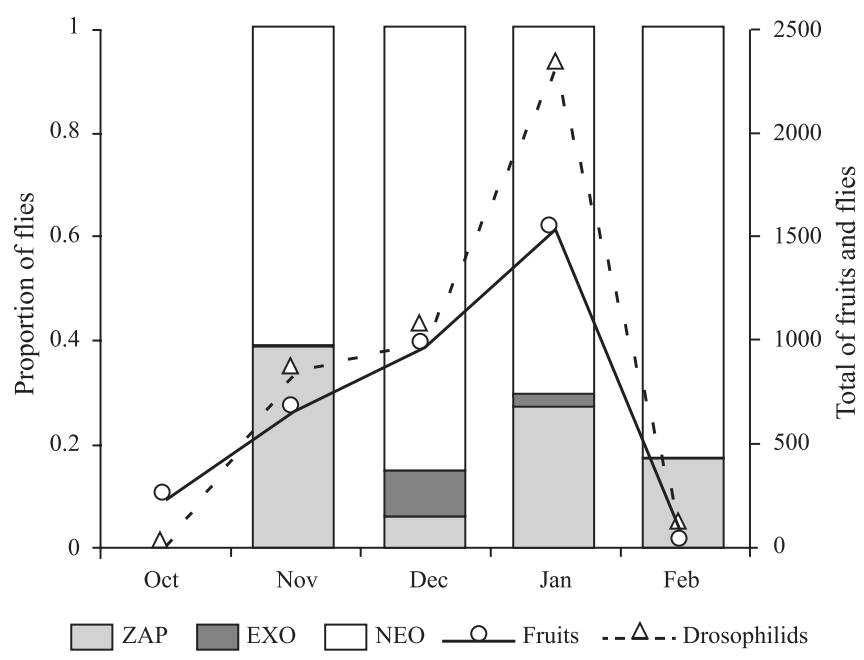

Fig. 3. Temporal fluctuation of the drosophilid assemblage breeding in Emmotum nitens, from October 2005 to February 2006. Bars represent the relative abundance of Zaprionus indianus (ZAP), Neotropical drosophilids (NEO) and exotic drosophilids, except Z. indianus (EXO). Lines represent the absolute abundance of flies and fruits over time.

Several drosophilid species avoid laying eggs on substrates with high densities of larvae (Medina-Muñoz \& Godoy-Herrera 2005; Wertheim et al. 2006). Competition among larvae is probably higher in such substrates and as result this behavior would tend to decrease species richness. This may have occurred in Hancornia speciosa, from whose fruits emerged 222 individuals of Zaprionus indianus, 118 of Drosophila nebulosa, and 18 individuals classified into three other species. Z. indianus is a recently introduced species into South America (Vilela 1999), probably from African savannas very similar to the habitats where $H$. speciosa occurs. It is possible that the presence of eggs of this species is preventing the oviposition of Neotropical drosophilids, and therefore contributes to the low richness in this resource, where the density of flies was the highest. The association between H. speciosa and drosophilids may be a good model to test the hypothesis of competition between endemic and exotic species, and we intend to perform future studies to study this mechanism.

The distribution of drosophilid assemblages in E. nitens also seems to reflect the availability of fruits in space and time since the abundance of flies varied with the availability of fruits under each tree and over time. The population peak of drosophilids in E. nitens was at the height of the wet season (January) when the availability of fruits in general is higher (Almeida et al. 1998). The high availability of resources in this period certainly contributed to the growth of the drosophilid populations, which are consumers of the yeasts and bacteria that decompose these fruits. These results support those obtained by Souza-Silva et al. (2001), which showed that the largest flower-visiting flies' densities also occur when resource availability is high, given appropriate environmental conditions. 
Table II. Relative abundance (\%) of drosophilids emerging from fallen fruits from six trees of Emmotum nitens, from October 2005 to February 2006, in the municipality of Sobradinho, Distrito Federal, Brazil.

\begin{tabular}{|c|c|c|c|c|c|c|c|}
\hline \multirow{2}{*}{ Drosophilid species } & \multicolumn{6}{|c|}{ Trees } & \multirow[t]{2}{*}{ Total } \\
\hline & 1 & 2 & 3 & 4 & 5 & 6 & \\
\hline Drosophila nebulosa & 43.69 & 59.08 & 53.33 & 71.33 & 100 & - & 48.81 \\
\hline Zaprionus indianus & 24.10 & 24.66 & 28.03 & 18.18 & - & 100 & 24.60 \\
\hline D. willistoni & 30.19 & 0.27 & 8.72 & 9.09 & - & - & 21.02 \\
\hline D. simulans & 1.31 & 9.76 & 1.71 & - & - & - & 2.81 \\
\hline D. bocainensis & 0.26 & 3.66 & 3.76 & 0.70 & - & - & 1.37 \\
\hline D. mediostriata & - & 0.54 & 3.25 & - & - & - & 0.55 \\
\hline D. cardini & - & 0.95 & 0.85 & - & - & - & 0.29 \\
\hline D. immigrans & 0.19 & - & - & 0.70 & - & - & 0.14 \\
\hline Drosophila sp. A & 0.04 & 0.27 & - & - & - & - & 0.07 \\
\hline D. cardinoides & - & 0.41 & - & - & - & - & 0.07 \\
\hline D. paraguayensis & 0.07 & - & 0.17 & - & - & - & 0.07 \\
\hline D. sturtevanti & 0.04 & - & 0.17 & - & - & - & 0.05 \\
\hline D. arauna & 0.04 & - & - & - & - & - & 0.02 \\
\hline D. mercatorum & 0.04 & - & - & - & - & - & 0.02 \\
\hline D. mesostigma & 0.04 & - & - & - & - & - & 0.02 \\
\hline D. ornatifrons & - & 0.14 & - & - & - & - & 0.02 \\
\hline D. polymorpha & - & 0.14 & - & - & - & - & 0.02 \\
\hline Scaptodrosophila latifasciaeformis & - & 0.14 & - & - & - & - & 0.02 \\
\hline Total number of drosophilids & 2,680 & 738 & 585 & 143 & 11 & 6 & 4,163 \\
\hline Total number of fruits & 1,855 & 526 & 705 & 231 & 81 & 37 & 3,435 \\
\hline Total fruit weight (g) & 8,419 & 2,317 & 2,827 & 1,050 & 202 & 154 & 14,969 \\
\hline Drosophilids/g fruit & 0.318 & 0.319 & 0.207 & 0.136 & 0.054 & 0.039 & 0.278 \\
\hline
\end{tabular}

Regarding the drosophilid assemblage composition in Emmotum nitens, the relative abundance of Neotropical species was always higher than that of exotics throughout the period of this study. These data confirm the idea that fallen fruits of this plant species represent an important resource for the maintenance of native drosophilids in the Cerrado biome.

In the tropics, where seasonal variation in temperature tends to be low, seasons usually reflect variations in precipitation and/or intensity of radiation. Understanding how tropical insect populations respond to seasonal variation is fundamental to explain their phenological patterns and life histories (Braby 1995; Pinheiro et al. 2002).

In conclusion, this study showed that drosophilid assemblages vary in space and time among resources, that the abundance of flies responds to resource availability, and that decaying fruits of Emmotum nitens are important breeding sites for Neotropical drosophilids.

Acknowledgements. We are grateful to F. S. T. Gomes for allowing us to collect on her farm, to R. Constantino for cooperation in the fieldwork and to R. Henriques for suggestions in previous versions of this manuscript. We are also grateful to the Universidade de Brasília for the logistic support and to CNPq and FAP-PRONEX for financial support.

\section{REFERENCES}

Almeida, S. P.; C. E. B. Proença; S. M. Sano \& J. F. Ribeiro. 1998. Cerrado: espécies vegetais úteis. Planaltina. Embrapa-CPAC. $\mathrm{xiii}+464 \mathrm{p}$.

Araújo, A. M. \& V. L. S. Valente. 1981. Observações sobre alguns lepidópteros e drosofilídeos do Parque do Turvo, RS. Ciência e Cultura 33: $1485-1490$.

Bächli, G. 2008. TaxoDros: The database on taxonomy of Drosophilidae. Consulted November 2008. URL: http:// taxodros.unizh.ch/.

Barroso, G. M.; A. L. Peixoto; C. G. Costa; C. L. F. Ichaso \& E. F. Guimarães. 1984. Sistemática de angiospermas do Brasil. Viçosa. Imprensa Universitária-UFV. 377 p.

Begon, M.; C. R. Townsend \& J. L. Harper. 2006. Ecology: From Individuals to Ecosystems (4th edition). Oxford. Blackwell Publishing. xii+738 p.

Bonorino, C. B. C. \& V. L. S. Valente. 1989. Studies on wild and urban populations and breeding sites of Drosophila nebulosa. Revista Brasileira de Biologia 49: 771-776.

Braby, M. F. 1995. Seasonal changes in relative abundance and spatialdistribution of Australian lowland tropical satyrine butterflies. Australian Journal of Zoology 43: 209-229.

Brake, I. \& G. Bächli. 2008. Drosophilidae (Diptera). In: World Catalogue of Insects 9: 1-412.

Brncic, D. \& V. L. S. Valente. 1978. Dinâmica de comunidades de Drosophila que se estabelecem em frutos silvestres no Rio Grande do Sul. Ciência e Cultura 30: 1104-1111.

Carson, H. L. 1971. The ecology of Drosophila breeding sites Harold L. Lyon Arboretum Lecture. Honolulu. University of Hawaii Press. 28 p.

Chassagnard, M. T. \& L. Tsacas. 1993. The subgenus Zaprionus s.str. Definition of species groups and revision of the Vittiger subgroup (Diptera, Drosophilidae). Annales de la Societe Entomologique de France 29: 173-194.

Colweel, R. K. 2005. EstimateS: Statistical estimation of species richness and shared species from samples. Version 7.5. User's Guide and application published at: http://purl.oclc.org/estimates.

Freire-Maia, N. \& C. Pavan. 1949. Introdução ao estudo da drosófila. Cultus 1: 1-171.

Frota-Pessoa, O. 1954. Revision of the tripunctata group of Drosophila with description of fifteen new species (Drosophilidae, Diptera). Arquivos do Museu Paranaense 10: 253-304. 
Grossfield, J. 1978. Non-sexual behavior of Drosophila, p. 1-126. In: Ashburner, M. \& T. R. F. Wright (eds.). The genetics and biology of Drosophila, v. 2b. London and New York. Academic Press. 452 p.

Klink, C. A. \& R. B. Machado. 2005. Conservation of the Brazilian Cerrado. Conservation Biology 19: 707-713.

Lachaise, D. \& L. Tsacas. 1983. Breeding-sites in tropical African Drosophilids, p. 221-332. In: Ashburner, M.; H. L. Carson \& J. N. Thompson (eds.). The genetics and biology of Drosophila, v. 3a. London. Academic Press. 382 p.

Leão, B. F. D. \& R. Tidon. 2004. Newly invading species exploiting native host-plants: the case of the African Zaprionus indianus (Gupta) in the fruits of the native Brazilian Cerrado (Diptera, Drosophilidae). Annales de la Societe Entomologique de France 40: 285-290.

Magalhães, L. E. 1962. Notes on the Taxonomy, Morphology, and Distribution of the saltans group of Drosophila, with Descriptions of four new Species. The University of Texas Publications 6205: 134-154.

Medina-Muñoz, M. C. \& R. Godoy-Herrera. 2005. Dispersal and prepupation behavior of Chilean sympatric Drosophila species that breed in the same site in nature. Behavioral Ecology 16: 316322 .

Myers, N.; R. A. Mittermeyer; C. G. Mittermeyer; G. A. B. Fonseca \& J. Kent. 2000. Biodiversity spots for conservation priorities. Nature 403: 853-858.

Oliveira, P. S. \& R. J. Marquis. 2002. The Cerrados of Brazil. New York. Columbia University Press. $\mathrm{x}+398$ p.

Pavan, C. \& J. Nacrur. 1950. Duas novas espécies de Drosophila (Diptera) do grupo annulimana. Dusenia 1: 263-274.

Pereira, M. A. Q. R.; C. R. Vilela \& F. M. Sene. 1983. Notes on breeding and feeding sites of some species of the repleta group of the genus Drosophila (Diptera, Drosophilidae). Ciência e Cultura 35: 1313-1319.

Pinheiro, F.; I. R. Diniz; D. Coelho \& M. P. S. Bandeira. 2002. Seasonal pattern of insect abundance in the Brazilian cerrado. Austral Ecology 27: 132-136.

Powell, J. R. 1997. Progress and Prospects in Evolutionary Biology: The Drosophila Model. Oxford. Oxford University Press. $\mathrm{xiv}+562 \mathrm{p}$.

Ratter, J. A.; J. F. Ribeiro \& S. Bridgewater. 1997. The Brazilian Cerrado vegetation and threats to its biodiversity. Annals of Botany 80: 223-230.

Ratter, J. A.; P. W. Richards; G. Argent \& D. R. Gifford. 1973. Observation on northeastern Mato Grosso. I The woody vegetation types of the Xavantina - Cachimbo expedition area. Philosophical Transactions of the Royal Society of London (B) 66: 449492.

Rohde, C. \& V. L. S. Valente. 1996. Ecological characteristics of urban populations of Drosophila polymorpha Dobzhansky and Pavan and Drosophila cardinoides Dobzhansky and Pavan (Diptera, Drosophilidae). Revista Brasileira de Entomologia 40: 75-79. Souza-Silva, M.; J. C. R. Fontenelle \& R. P. Martins. 2001. Seasonal abundance and species composition of flower-visiting flies. Neotropical Entomology 30: 351-359.

Tidon, R. 2006. Relationships between drosophilids (Diptera, Drosophilidae) and the environment in two contrasting tropical vegetations. Biological Journal of the Linnean Society 87: 233-247.

Tidon, R.; D. F. Leite \& B. F. D. Leão. 2003. Impact of the colonization of Zaprionus (Diptera: Drosophilidae) in different ecosystems of the Neotropical Region: 2 years after the invasion. Biological Conservation 112: 299-305.

Toda, M. J. 1973. Seasonal activity and microdistribution of drosophilid flies in Misumai in Sapporo. Journal of Faculty of Sciences, Hokkaido University 18: 532-550.

Val, F. C. 1982. The male genitalia of some Neotropical Drosophila: notes and illustrations. Papéis Avulsos de Zoologia 34: 309347 .

Val, F. C.; C. R. Vilela \& M. D. Marques. 1981. Drosophilidae of the Neotropical region, p. 123-168. In: Ashburner, M.; H. L. Carson \& J. N. Thompson (eds.). The genetics and biology of Drosophila, v. 3a. London. Academic Press. 429 p.

Valente, V. L. S. \& A. M. Araújo. 1986. Comments on breeding sites of Drosophila willistoni Sturtevant (Diptera, Drosophilidae). Revista Brasileira de Entomologia 30: 281-286.

Valente, V. L. S. \& A. M. Araújo. 1991. Ecological aspects of Drosophila species inhabiting wild environments in Southern Brazil (Diptera: Drosophilidae). Revista Brasileira de Entomologia 35: 237253 .

Vilela, C. R. 1983. A revision of the Drosophila repleta species group (Diptera, Drosophilidae). Revista Brasileira de Entomologia 27: $1-114$.

Vilela, C. R. 1999. Is Zaprionus indianus Gupta 1970 (Diptera, Drosophilidae) currently colonizing the Neotropical region? Drosophila Information Service 82: 37-39.

Vilela, C. R. 2001. Breeding sites of Neotropical Drosophilidae (Diptera). III. Rotting infructescences of Philodendron bipinnatifidum (Araceae). Revista Brasileira de Entomologia 46: 339-344.

Vilela, C. R. \& G. Bächli. 1990. Taxonomic studies on Neotropical species of seven genera of Drosophilidae (Diptera). Mitteilungen der Schweizerischen Entomologischen Gesellschaft 63: 1332 .

Wertheim, B.; R. Allemand; L. E. M. Vet \& M. Dicke. 2006. Effects of aggregation pheromone on individual behaviour and food web interactions: a field study on Drosophila. Ecological Entomology 31: 216-226.

Wolda, H. 1988. Insect seasonality: Why? Annual Review of Ecology and Systematics 19: 1-18. 